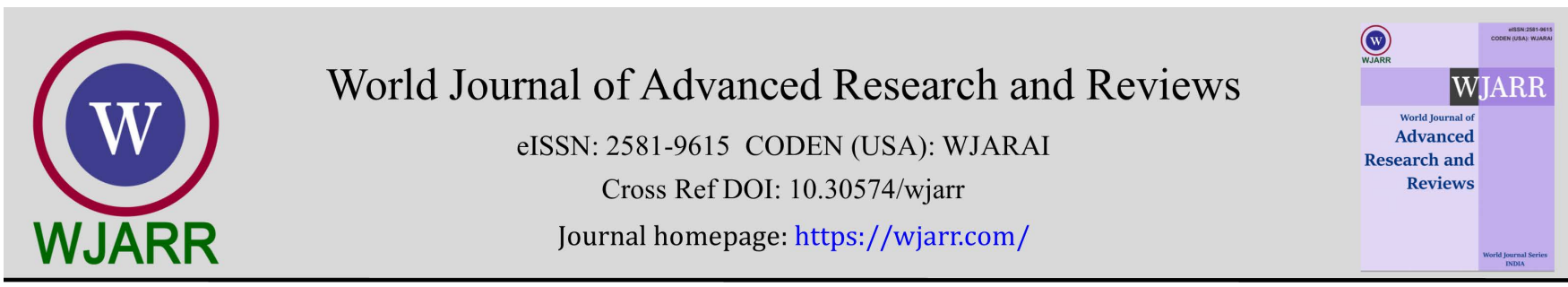

(RESEARCh ARTICLE)

Check for updates

\title{
Isolation and characterization of plant growth-promoting endophytic bacteria of wild legumes growing on sandy soils of Binh Thuan province, Vietnam
}

\author{
Dang Thi Ngoc Thanh ${ }^{1 *}$, Pham Thi Thu Ly ${ }^{2}$, Pham Thi Nga ${ }^{3}$ and Pham Van Ngot 4 \\ ${ }^{1}$ Faculty of Natural Science Pedagogy, Sai Gon University, 273 A Duong Vuong Street, Ward 3, District 5, Ho Chi Minh City, \\ Vietnam. \\ 2 Department of Facility Management, Sai Gon University, 273 A Duong Vuong Street, Ward 3, District 5, Ho Chi Minh City, \\ Vietnam. \\ ${ }^{3}$ Nguyen Dinh Chieu High School, 814 Binh Duong Avenue, Hiep Thanh Ward, Thu Dau Mot City, Binh Duong Province, \\ Vietnam. \\ ${ }^{4}$ Faculty of Biology, HCMC University of Education, 280 A Duong Vuong Street, Ward 4, District 5, Ho Chi Minh City, Vietnam.
}

World Journal of Advanced Research and Reviews, 2021, 10(03), 246-254

Publication history: Received on 05 May 2021; revised on 10 June 2021; accepted on 13 June 2021

Article DOI: https://doi.org/10.30574/wjarr.2021.10.3.0274

\begin{abstract}
The roots of two legume species (Tephrosia purpurea and Tephrosia villosa) that grew wild on dry sandy soils of Binh Thuan province were sources for isolating plant growth-promoting endophytic bacteria. Semi-solid LGI medium was used for the isolation of nitrogen-fixing bacteria from root extracts. All bacterial isolates isolates were evaluated for their ability to solubilize calcium orthophosphate on solid NBRIP medium and their ability to produce IAA in Burk's liquid medium supplemented with $100 \mathrm{mg} / \mathrm{L}$ tryptophan. The possibilities of nitrogen fixation, phosphate solubilization and IAA synthesis were all quantitative examined by colorimetric method. Twenty-two bacterial isolates of T. purpurea and 18 isolates of T. villosa were capable of nitrogen fixation in the range of 1.94 to $2.81 \mathrm{mg} / \mathrm{L} \mathrm{NH}_{4}{ }^{+}$, whereas only 18 isolates of T. purpurea and 16 isolates of T. villosa showed phosphate solubilization in the range of $12.30-48.90 \mathrm{mg} / \mathrm{L}$ $\mathrm{P}_{2} \mathrm{O}_{5}$, and IAA production in the range of $0.38-12.72 \mathrm{mg} / \mathrm{L}$. Sixteen outstanding bacterial isolates of the two legume species were identified by MALDI-TOF technique. The results showed that 13 isolates had high similarity with five bacterial genera including Klebsiella, Cronobacter, Enterobacter, Burkholderia, and Bacillus with score values in the range of $2.070-2.411$.
\end{abstract}

Keywords: Tephrosia purpurea; Tephrosia villosa; Binh Thuan province; Plant growth-promoting bacteria; Endophytic bacteria; MALDI-TOF technique

\section{Introduction}

Binh Thuan in the South-Central Coast of Vietnam has geographical coordinates from $10^{\circ} 33^{\prime} 42^{\prime \prime}$ to $11^{\circ} 33^{\prime} 18^{\prime \prime}$ north latitude and from $107^{\circ} 23^{\prime} 41^{\prime \prime}$ to $108^{\circ} 52^{\prime} 18^{\prime \prime}$ east longitude. Low mountainous terrain here accounts for $72.35 \%$ of the natural area, narrow coastal plains account for only $9.43 \%$. Meanwhile, beaches and sand dunes account for $18.22 \%$ [1]. This is also the region with the driest climate in the country, arid soils, desertification and surface salinization occur in many places. All of which make agricultural development difficult. Fortunately, studies showed that plants growing in drought, water-deprived or salt-accumulating conditions had developed special strategies for adaptation, including the selection of specific combinations of PGPB (Plant Growth-Promoting Bacteria) [2]. PGPB had the ability to promote plant growth through direct mechanisms such as nitrogen fixation, phosphate solubilization, phytohormones production. In addition, biological control, biodegradation, environmental stress control abilities of these bacteria enhanced host plant

\footnotetext{
* Corresponding author: Dang Thi Ngoc Thanh

Faculty of Natural Science Pedagogy, Sai Gon University, 273 An Duong Vuong Street, Ward 3, District 5, Ho Chi Minh City, Vietnam. Copyright (C) 2021 Author(s) retain the copyright of this article. This article is published under the terms of the Creative Commons Attribution Liscense 4.0.
} 
health, helped plant to withstand adverse environmental conditions [3]. These mechanisms were considered to promote plant-growth indirectly. PGPB included rhizopheric, endophytic, or symbiotic bacteria that were grouped according to the degree of interaction between the bacteria and the host plant [4].

Concerning wild legumes, they were suggested to have a wide distribution in arid regions and contribute positively to soil fertility through their $\mathrm{N}_{2}$ fixation and tolerance to extreme conditions which to be suggested higher than that of cultivated legumes. The access to soil phosphorus of cover plants was also often superior to that of main crops. These possibilities were attributed to interactions between the host plant and microorganisms such as rhizobia or other soil microbes $[5,6]$. Incorporation of cover plants into crop rotation generally increased the yield of the main crop. Rice yields in wetlands were significantly improved by Fabaceae cover plants [6]. In Binh Thuan, Vietnam, Pinto peanut (Arachis pintoi) were also encouraged to be planted as cover plants for dragon fruit trees, replacing the previous rice straw mulch because in addition to moisture retention and erosion control, it also helped to increase soil fertility [7]. In Botswana, identification of PGPBs in the soil layer $10-15 \mathrm{~cm}$ under the canopy of Tephrosia purpurea by soil DNA analysis (culture-independent method) revealed that the main phyla were Proteobacteria, Firmicutes and Actinobacteria. Other taxa included Gemmatimonadetes, Acidobacteria, and Planctomycetes. In culture-dependent method, in the nodules of legumes including Vigna unguiculata, Macroptilium atropurpureum and Tephrosia virginiana, some PGPB rhizobia and Bacillus species and several opportunistic bacteria were finding out [8].

In previous surveys by the authors, Pham et al. [9], and other unpublished data, Tephrosia purpurea, Tephrosia villosa, and many other wild legumes such as Indigofera hirsuta, Crotalaria retusa, Desmodium triflorum in Binh Thuan province were herbaceous plants that had the use of folk medicine, as well as cover plants of main crops to improve soil fertility. This was the basis of the initial study of endogenous PGPB in two common wild legume species of the region, Tephrosia purpurea and Tephrosia villosa.

\section{Material and methods}

\subsection{Sample's collection and preparation}

Samples were collected in two communes of Mui Ne (coordinates $10^{\circ} 57^{\prime} 15.84^{\prime \prime} \mathrm{N}, 108^{\circ} 17^{\prime} 34.31^{\prime \prime} \mathrm{E}$ ) and Tien Thanh (coordinates $10^{\circ} 50^{\prime} 58.35^{\prime \prime} \mathrm{N}, 108^{\circ} 1^{\prime} 24.21 " \mathrm{E}$ ) of Phan Thiet city, Binh Thuan province in June 2020. Five sites were randomly selected in each commune. Three plant samples of each species (Tephrosia purpurea and Tephrosia villosa) were collected at each site, making up 15 samples were taken per each commune. The aerial parts that $20 \mathrm{~cm}$ above the ground of each plant ( $0.5-1.0$ meter high) were cut off. The rest of the stem and roots and the soil surrounding the roots were collected, packed, labeled and transported to the laboratory.

\subsection{Isolation and morphology characterization of endophytic bacteria had capable of fixing nitrogen and solubilizing phosphate}

In the laboratory, the soil around the roots was removed. The roots were washed under running water tap and subjected to sample sterilization and extraction procedures [10]. The extracts were then inoculated into test tubes containing semi-solid N-free LGI medium to observe the presence of bacteria (in the form of pellicles) for repeated streaking onto LGI agar to obtain pure colonies [10].

The nitrogen-fixing bacterial isolates collected after culture on LGI medium were streaked to NBRIP agar medium containing calcium orthophosphate for screening phosphate solubilizing capability. Any isolate that could grow on this medium and form a halo around the colony could be considered phosphate solubilization bacteria [10].

The collected bacterial isolates were recorded for colony and cell morphology by means of Gram staining, magnifying glass, microscope, stereomicroscope, and scanning electron microscope.

\subsection{PGP functional characterization of endophytic bacterial isolates}

\subsubsection{Abilities of nitrogen fixing and phosphate solubilizing}

All bacterial isolates on LGI medium were tested for nitrogen fixation and all isolates grown on NBRIP medium were tested for phosphate solubilization by quantitative through the colorimetric method. A loop of bacterial biomass of each isolate was inoculated in $10 \mathrm{~mL}$ LGI or NBRIP broth and incubated at $120 \mathrm{rpm}$ (round per minute), and $28 \pm 2^{\circ} \mathrm{C}$ to prepare the suspension. After 2 days, a fit volume of the suspension was added to LGI or NBRIP broth to form $50 \mathrm{~mL}$ solution had the turbidity of the McFarland Standard $0.5\left(1.5 \times 10^{\wedge} 8 \mathrm{CFU} / \mathrm{mL}\right)$ and was continuously cultured in a period. The suspension was then collected periodically at 2, 4, 6, 8 DAI (days after inoculation) to quantitative 
ammonium by the indophenol blue colorimetric method at a wavelength of $640 \mathrm{~nm}$. Similarly, the quantification of soluble phosphate took place at 5, 10, 15, 20 DAI by the molybdate colorimetric method at $880 \mathrm{~nm}$ [11].

\subsubsection{Ability of IAA producing}

The bacterial isolates with both nitrogen fixation and phosphate solubilization were grown in Burk's broth supplemented with $100 \mathrm{mg} / \mathrm{L}$ tryptophan (Trp) [10] and incubated at $28 \pm 2^{\circ} \mathrm{C}$ in the dark for 7 days. After incubation, $0.25 \mathrm{~mL}$ of the suspension was collected and mixed with $1.0 \mathrm{~mL}$ of Salkowski reagent $\left(0.5 \mathrm{M} \mathrm{FeCl}_{3}\right.$, distilled water, and concentrated $\mathrm{H}_{2} \mathrm{SO}_{4}$ in a proportion of 1:50:30 v/v/v) [12] to detect isolates capable of producing IAA which turned the reagent pink. A fit volume of each bacterial suspension was added to Burk's broth supplemented with $100 \mathrm{mg} / \mathrm{L}$ Trp to form $50 \mathrm{~mL}$ solution had the turbidity of the McFarland Standard 0.5 and cultured in the dark. The quantification of IAA took place at 2, 4, 6, 8 DAI by the colorimetric method. The sample and reagent portion were 1:4 v/v. After 15 minutes of incubated in the dark, the absorbance of the sample was measured at a wavelength of $530 \mathrm{~nm}$ [12].

The quantitative experiments were repeated 3 times in a completely randomized design. The obtained data were tested with one-way analysis of variance and Duncan's test with an alpha of 0.05 using SPSS software.

\subsection{Molecular fingerprinting characterization of selected bacterial isolates}

This experiment was limited to the selected bacterial isolates with the best quantitative results. These isolates were cultured on LB agar medium for 24 hours and then identified by the MALDI-TOF MS method (Bruker Daltonik Maldi Biotyper System). The characteristic spectrum pattern of this proteomic fingerprint was used to reliably identify a particular microorganism by matching thousands of reference spectra from microorganism strains. According to the specifications of the manufacturer, a highly probable species identification had a score value ranged between 2.300 and $3.000[11]$.

\section{Results and discussion}

\subsection{Colony and cell morphology of endophytic bacteria}

There were 22 bacterial isolates obtained from the root sample extract of Tephrosia purpurea and 18 isolates obtained from Tephrosia villosa. All these bacteria were isolated from pellicles (Figure 1A) and grown on nitrogen-free LGI medium, so they were considered endophytic nitrogen-fixing bacteria $[3,10]$.
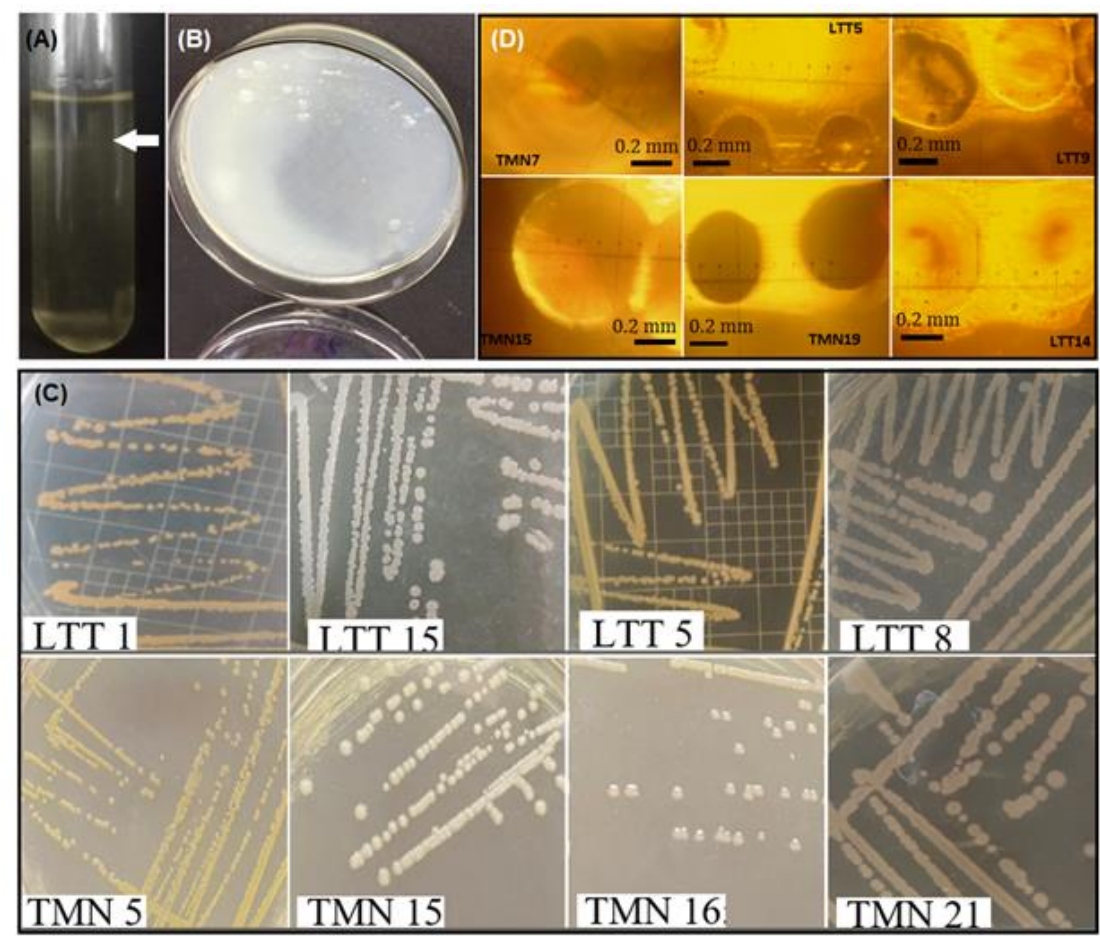

Figure 1 Colony morphology of some endophytic bacterial isolates 
On LGI medium, most colonies were smooth, translucent white or yellow (Figure 1B) as described by Hoang MT et.al, [3] and Dang Thi NT et.al,[10]. When the bacteria were transferred to LB medium, the colonies had a more distinct morphology [10]. The main characteristics of bacterial colonies of plants Tephrosia purpurea and Tephrosia villosa, respectively, were circular (95.5\% and 100\%), entire (100\% and $94.5 \%)$, convex (95.5\% and $88.9 \%)$, and opaque white (50\% and 22.2\%). The colonies of endophytic bacterial of Tephrosia villosa also had dominant colors including orange (33.3\%), and creamy-white (27.8\%) (Figure 1C). Colonie sizes ranged from about 0.1 to $2.5 \mathrm{~mm}$ (Figure 1D; the yellow color was due to the lights in the stereomicroscope).

The results of double staining showed that Gram-negative bacteria were dominant in the endophytic isolates of plants Tephrosia purpurea and Tephrosia villosa, accounting for 95.5\% and 94.5\%, respectively (Figure 2A). All isolates had rod shapes from short $(1.1 \mu \mathrm{m})$ to medium $(1.6 \mu \mathrm{m})$ (Figure $2 \mathrm{~B}$ ). These were common characteristics found in endophytic bacteria of plants grown in Vietnam [13].

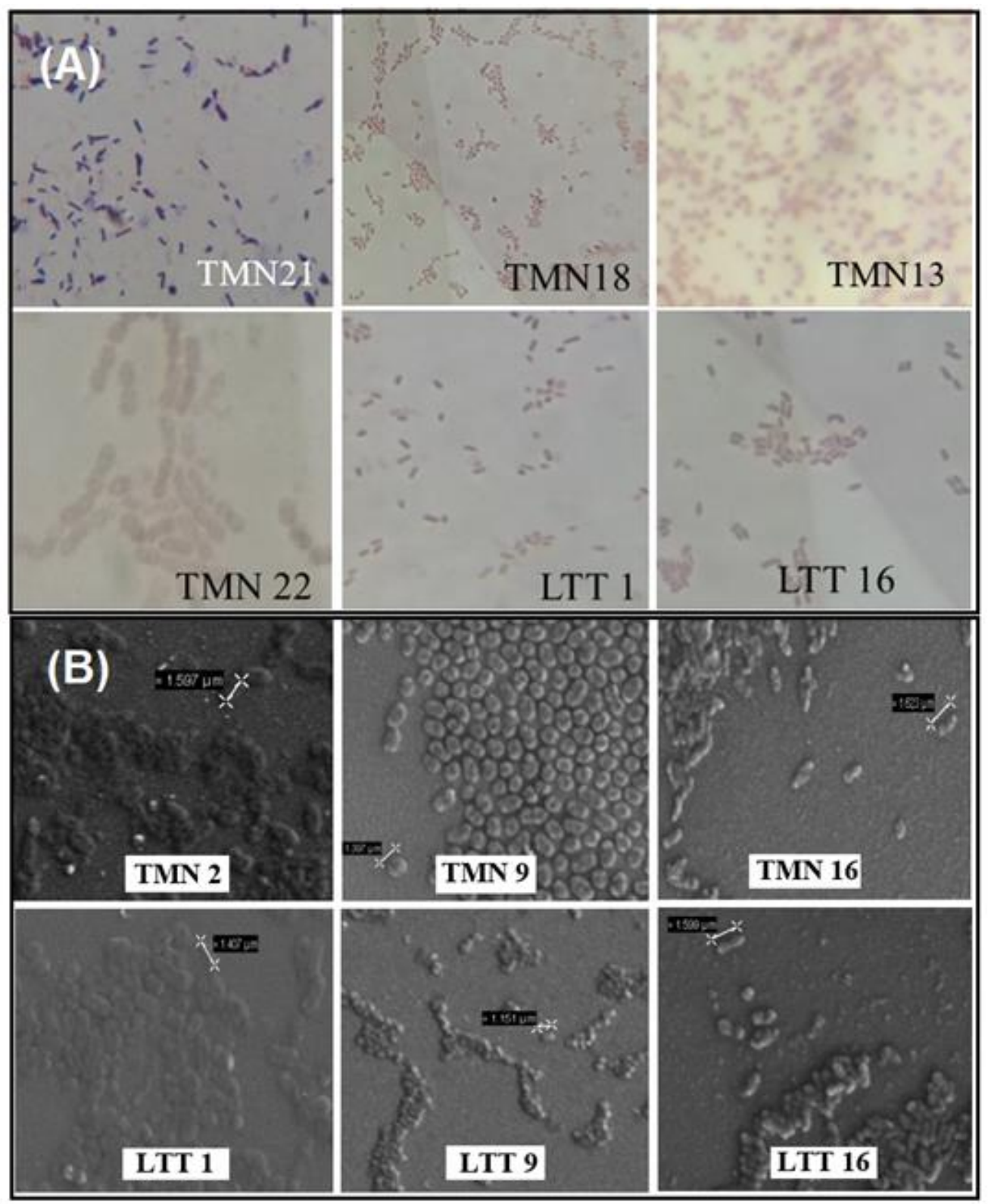

Figure 2 Gram stain results and SEM images of some endophytic bacterial isolates

\subsection{Abilities of nitrogen fixing, phosphate solubilizing and IAA producing of endophytic bacteria}

Eighteen bacterial isolates out of 22 endophytic isolates of Tephrosia purpurea were able to solubilize phosphate, accounting for $81.8 \%$. Similarly, this data for Tephrosia villosa was 16 isolates, accounting for $88.9 \%$. The mean 
quantitative results of four measurements of ammonium, phosphate and IAA of endophytic bacteria ranged from 1.94 - $2.81 \mathrm{mg} / \mathrm{L} \mathrm{NH}_{4}+12.30$ - $48.90 \mathrm{mg} / \mathrm{L} \mathrm{P}_{2} \mathrm{O}_{5}$ and 0.38 - $12.72 \mathrm{mg} / \mathrm{L}$ IAA. Thereby, 16 isolates were selected for identification based on good quantitative results (Table 1). The values presented were the maximum of the four sample measurements for each treatment (measurement dates were indicated in parentheses).

Table 1 PGP functional characteristics of 16 selected isolates

\begin{tabular}{|c|c|c|c|c|}
\hline \multirow{2}{*}{ Source } & \multirow{2}{*}{ Isolate } & $\mathrm{N}_{2}$ fixation & P solubilization & IAA production \\
\hline & & $\left(\mathrm{Mg} \mathrm{NH}_{4}^{+} / \mathrm{L}\right)$ & $\left(\mathrm{Mg} \mathrm{P}_{2} \mathrm{O}_{5} / \mathrm{L}\right)$ & (Mg IAA /L) \\
\hline \multirow[t]{8}{*}{ Tephrosia purpurea } & TMN2 & $3.00^{\mathrm{ab}}(6 \mathrm{DAI})$ & $103.38^{\mathrm{ef}}(15 \mathrm{DAI})$ & $1.49^{\mathrm{hi}}(4 \mathrm{DAI})$ \\
\hline & TMN5 & $3.18^{\mathrm{b}}(2 \mathrm{DAI})$ & $29.84^{\mathrm{h}}(15 \mathrm{DAI})$ & $2.60^{\text {gh }}(4 \mathrm{DAI})$ \\
\hline & TMN9 & $2.94^{\mathrm{ab}}(6 \mathrm{DAI})$ & $108.23^{\operatorname{def}}(15 \mathrm{DAI})$ & $13.10^{\mathrm{ab}}(2 \mathrm{DAI})$ \\
\hline & TMN13 & $2.96^{\text {def }}(8 \mathrm{DAI})$ & $136.88^{\mathrm{abc}}(15 \mathrm{DAI})$ & $11.31^{\mathrm{c}}(2 \mathrm{DAI})$ \\
\hline & TMN15 & $2.97^{\mathrm{ab}}(6 \mathrm{DAI})$ & $129.84^{\text {abcd }}(15$ DAI $)$ & $13.90^{\mathrm{a}}(2 \mathrm{DAI})$ \\
\hline & TMN16 & $2.55^{\mathrm{g}}(8 \mathrm{DAI})$ & 137.59ab (15 DAI) & $12.83^{\mathrm{ab}}(4 \mathrm{DAI})$ \\
\hline & TMN18 & $2.71^{\mathrm{fg}}(8 \mathrm{DAI})$ & $124.69^{\text {abcde }}$ (15 DAI) & $3.82^{\mathrm{ef}}(8 \mathrm{DAI})$ \\
\hline & TMN21 & $3.10^{\mathrm{ab}}(8 \mathrm{DAI})$ & $52.05^{g}(15 \mathrm{DAI})$ & $1.48^{\mathrm{d}}(6 \mathrm{DAI})$ \\
\hline \multirow[t]{8}{*}{ Tephrosia villosa } & LTT1 & $2.51^{\mathrm{ef}}(8 \mathrm{DAI})$ & $96.40^{\mathrm{ab}}(15 \mathrm{DAI})$ & $1.38^{\mathrm{ab}}(8 \mathrm{DAI})$ \\
\hline & LTT3 & $3.04^{\mathrm{bcd}}(6 \mathrm{DAI})$ & $87.44^{\mathrm{ab}}(15 \mathrm{DAI})$ & $5.39^{\mathrm{ab}}(6 \mathrm{DAI})$ \\
\hline & LTT5 & $3.09^{\mathrm{abc}}(6 \mathrm{DAI})$ & $90.84^{\mathrm{ab}}(15 \mathrm{DAI})$ & $7.06^{\mathrm{a}}(6 \mathrm{DAI})$ \\
\hline & LTT8 & $3.18^{\mathrm{a}}(6 \mathrm{DAI})$ & $84.69^{\mathrm{ab}}(15 \mathrm{DAI})$ & $5.72^{\text {cde }}(4 \mathrm{DAI})$ \\
\hline & LTT9 & $3.01^{\mathrm{abc}}(8 \mathrm{DAI})$ & $96.38^{\mathrm{ab}}(15 \mathrm{DAI})$ & $3.19^{\text {cdef }}(6 \mathrm{DAI})$ \\
\hline & LTT13 & $3.12^{\mathrm{a}}(8 \mathrm{DAI})$ & $98.22^{\mathrm{ab}}(15 \mathrm{DAI})$ & $3.77^{b c}(4 \mathrm{DAI})$ \\
\hline & LTT16 & $2.85^{\mathrm{a}}(2 \mathrm{DAI})$ & $75.82^{\mathrm{b}}(15 \mathrm{DAI})$ & $0.72^{\mathrm{e}}(8 \mathrm{DAI})$ \\
\hline & LTT17 & 2.94abcd (8 DAI) & $107.51^{\mathrm{a}}(15 \mathrm{DAI})$ & 1.63cde (8 DAI) \\
\hline
\end{tabular}

The data in the table were statistically processed by isolation origin of bacteria (source), and by sample measurement date (indicated in parentheses). The values with different superscript letters in the same statistical group were significantly different at $\alpha=0.05$ by the Duncan test.

The data in Table 1 showed that all selected isolates had the highest soluble phosphate on day 15 after inoculation. Meanwhile, nitrogen fixation capacity was usually high at 8 DAI or 6 DAI, and IAA synthesis capacity was usually high at 2 DAI or 4 DAI (Figure 3). Inferior IAA-synthesizing isolates had the highest data obtained on day 8 after inoculation. Among the 16 selected isolates, there were some that best represent all three possibilities examined, such as TMN15, LTT5, and LTT8. Regarding the origins of bacteria, the bacterial isolates of Tephrosia purpurea were better able to solubilize phosphate and synthesize IAA, while the isolates of Tephrosia villosa had better nitrogen fixation.

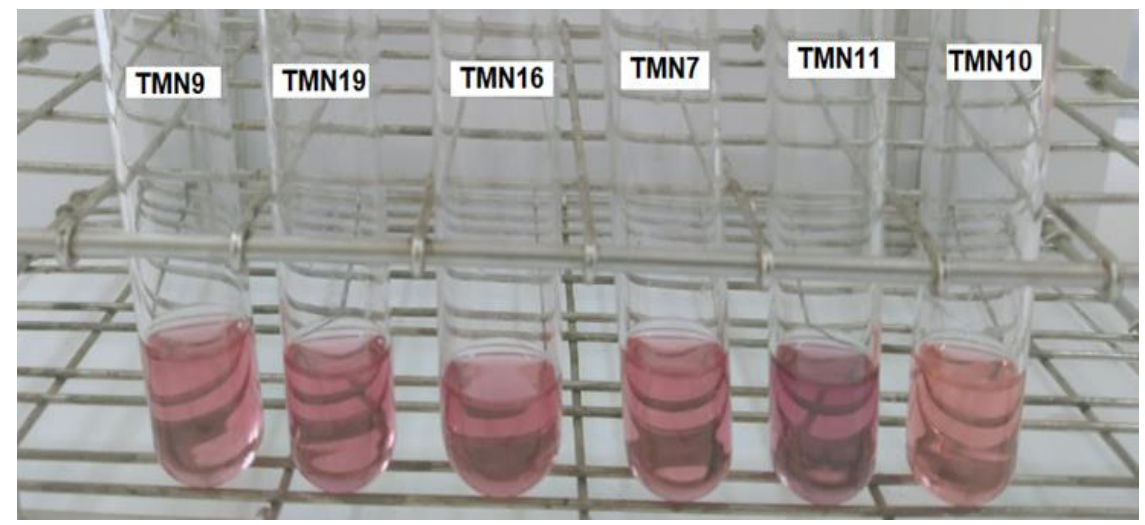

Figure 3 Indole-3-acetic acid production by some endophytic bacterial isolates at 4 DAI 
The possession of many PGP properties by root nodule endophytes of T. purpurea and T. villosa was reported. In the research of Poonar et al. [14], 100\% of root nodule bacterial isolates of T. purpurea and T. villosa were found ammonia producing, but more than $50 \%$ of isolates were observed the phosphate solubilization trait, and only $25 \%$ of them were detected the ability of IAA producing. Plants of the Leguminosae are associated with the concept of $\mathrm{N}_{2}$ fixation and symbiotic bacteria (rhizobia). The main symbiotic genera of T. purpurea and T. villosa were Bradyrhizobium and Ensifer (Sinorhizobium). However, the symbiosis and nodulation ability of many other bacteria other than rhizobia such as Burkholderia, Pseudomonas, and Paenibacillus was also discovered by Andrews and Andrews [15], which was the basis for research on the diversity of species.

\subsection{Identification results of selected isolates}

The results of identification by MALDI-TOF technique (Table 2) were compared with profiles of selected isolates in terms of morphology and Gram staining. Thereby, 16 bacterial isolates were identified as belonging to 7 genera and 10 species including Sphingomonas phyllosphaerae (LTT1), Burkholderia gladioli (LTT16, LTT17), Pantoea septica (TMN5), Klebsiella pneumoniae (TMN9, TMN13, TMN15), Cronobacter sakazakii (TMN2, LTT3, LTT5, LTT13), Enterobacter radicincitans (TMN16), E. cloacae (TMN18), E. asburiae (LTT9), Bacillus subtilis (LTT8), and B. infantis (TMN21).

Table 2 Identification results of 16 selected isolates

\begin{tabular}{|c|c|c|c|}
\hline Isolate & Quality symbol & Organism Identification (best match) & Score Value \\
\hline TMN2 & $(+++)$ & Cronobacter sakazakii & 2.411 \\
\hline TMN5 & $(+)$ & Pantoea septica & 1.794 \\
\hline TMN9 & $(++)$ & Klebsiella pneumoniae & 2.200 \\
\hline TMN13 & $(++)$ & Klebsiella pneumoniae & 2.204 \\
\hline TMN15 & $(++)$ & Klebsiella pneumoniae & 2.285 \\
\hline TMN16 & $(+)$ & Enterobacter radicincitans & 1.845 \\
\hline TMN18 & $(++)$ & Enterobacter cloacae & 2.267 \\
\hline TMN21 & $(++)$ & Bacillus infantis & 2.048 \\
\hline LTT1 & $(+)$ & Sphingomonas phyllosphaerae & 1.792 \\
\hline LTT3 & $(++)$ & Cronobacter sakazakii & 2.101 \\
\hline LTT5 & $(++)$ & Cronobacter sakazakii & 2.298 \\
\hline LTT8 & $(++)$ & Bacillus subtilis & 2.101 \\
\hline LTT9 & $(++)$ & Enterobacter asburiae & 2.070 \\
\hline LTT13 & $(++)$ & Cronobacter sakazakii & 2.201 \\
\hline LTT16 & $(+++)$ & Burkholderia gladioli & 2.345 \\
\hline LTT17 & $(+++)$ & Burkholderia gladioli & 2.409 \\
\hline
\end{tabular}

Symbol description: (+++) highly probable species identification; (++) secure genus identification, probable species;

$(+)$ probable genus identification.

The reliability of the results showed that three isolates were identified at the "probable genus" level including TMN5, TMN16 and LTT1 (score values ranged between 1.700 and 1.999). Three isolates identified to the species level with high reliability were TMN2, LTT16 and LTT17 (score values ranged between 2.300 and 3.000). The remaining ten isolates were identified at the "secure genus" and "probable species" level (score values ranged between 2.000 and 2.299). Among thirteen isolates had higher similarity, Proteobacteria (Gram-negative) were more numerous than Firmicutes (Gram-positive) (84.6\% in comparison to $15.4 \%$ ) (Figure 4A). The class Gamma-proteobacteria was dominant (76.9\%) (Figure 4B), of which the genus Cronobacter (species sakazakii) had 4 isolates (Figure 4C), accounting for $30.8 \%$ of the total number of identified isolates. 

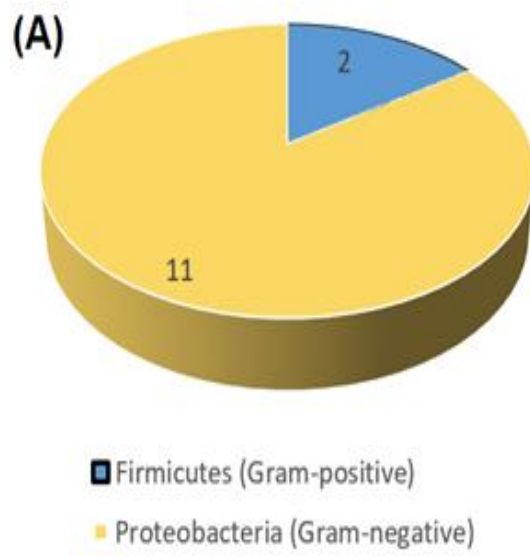

(B)
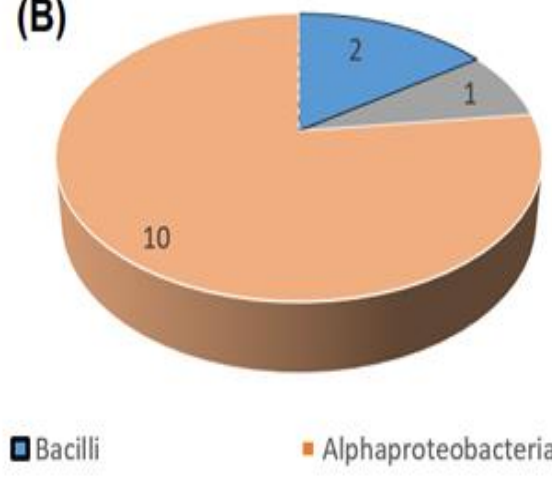

" Betaproteobacteria
(C)

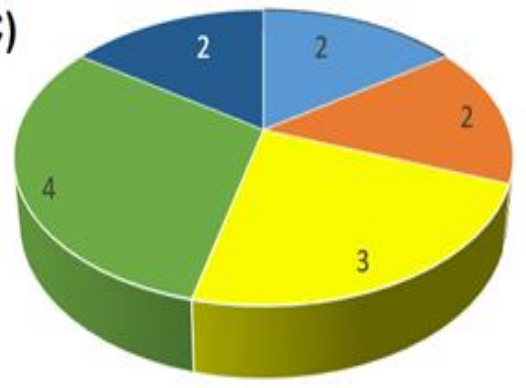

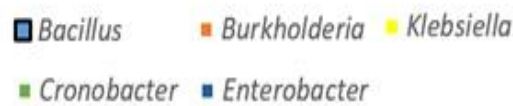

Figure 4 Grouping 16 identified bacterial isolates by phylum (A), class (B), and genus (C). (The number of isolates represented in the data of the chart)

Analysis of the composition of soil microbial communities around T. purpurea grown in Botswana by environmental DNA analysis showed that Proteobacteria and Firmicutes were the two dominant phyla, in which Proteobacteria accounted for more than $20 \%$. Bacterial isolation from the root nodules of cowpeas grown with this soil also detected bacteria other than rhizobia, including Bacillus safensis, B. pumilus, Burkholderia dolosa. DNA of Sphingomonas and many other bacterial genera was also detected in the soil but was not isolated in the root nodules [8].

Sphingomonas phyllosphaerae was a new bacterial species isolated from the phyllosphere of a leguminous tree, Acacia caven, growing in central Argentina [16]. The two bacterial strains FA1 and FA2 (T) of this species were Gram-negative, aerobic, rod-shaped, and motile and form yellow colonies on nutrient agar. Gram staining, colony and cell morphology, and SEM image of the isolate LTT1 in the present study showed similarities with the description of Rivas et al. [16]. The isolate LTT1 also had a good ability to dissolve phosphate, so it was possible to study more about the identification before putting it into application studies.

The remaining bacteria were well known for their PGP properties and plant association. Klebsiella pneumoniae was reported for nitrogen fixation [17], antagonism and plant growth promotion [18]. Enterobacter sp. SA187 was an endophytic bacterium strain isolated from the nodules of the desert legume Indigofera argentea. This strain was capable of producing IAA, solubilizing phosphate and providing tolerance to abiotic stress in the model plant Arabidopsis thaliana [19]. Besides Enterobacter, other genera including Pseudomonas, Burkholderia, Pantoea and Bacillus were also extensively studied for phosphate solubilizing bacteria (PSB) [20]. Particularly, Bacillus infantis, currently only information about strain SKS1 (isolated from garden soil of Guru Nanak Dev University campus, India) was capable and produces thermostable alkaline protease [21]. However, given the wide adaptability of this genus, it was quite possible to isolate Bacillus infantis from plants as shown in the present study. Attention should be paid to the opportunistic pathogenicity of this bacterial species.

The presence of legume-associated plant growth-promoting bacteria probably contributed to the good properties of the plants when used as cover crops or green manure. Using Tephrosia purpurea as a cover crop had the potential to increase the yield of the main crop by $25 \%$. In addition to the nitrogen fixation capacity, the increase in yield was thought to be through the enhancement of phosphorus (P) nutrient sources due to adaptations in root morphology and structure; mobilization of insoluble inorganic P or mineralization of organic P; and the interaction and selection of beneficial soil microbiota [6].

\section{Conclusion}

This study collected 34 plant growth-promoting bacterial isolates capable of nitrogen fixation, phosphate solubilization and IAA production from within the roots of Tephrosia purpurea and Tephrosia villosa. Sixteen isolates of them were identified, including well-known species in the field in question. The above data had shown the potential of research and application of these endophytic bacteria in enhancing plant nutrition. In addition to the antibacterial ability of folk medicinal plants, Tephrosia purpurea and Tephrosia villosa could be applied as cover crops in places with rather harsh agro-ecological conditions such as in the arid sandy soil of Binh Thuan, Vietnam. 


\section{Compliance with ethical standards}

\section{Acknowledgments}

The authors would like to thank Center for Bioscience and Biotechnology, VNUHCM-University of Science for identification experiment and Biotechnology Center of Ho Chi Minh City for SEM image recording.

\section{Disclosure of conflict of interest}

There is no conflict of interest between the authors as they all contributed to conducting the research and writing the article.

\section{References}

[1] Binh Thuan Portal [Internet]. 2018 [cited 2021 May 1]. Available from: https://www.binhthuan.gov.vn/Default.aspx?sid=4\&pageid=468

[2] Soussi A, Ferjani R, Marasco R, Guesmi A, Cherif H, Rolli E, et al. Plant-associated microbiomes in arid lands: Diversity, ecology and biotechnological potential. Plant and Soil. 2016 May 28;405(1/2):357-370.

[3] Hoang MT, Dang Thi NT, Cao ND. Functional and molecular characterization of plant growth promoting bacteria associated with sugarcane cultivated in Tay Ninh Province, Vietnam. GSC Biological and Pharmaceutical Sciences. 2020 May21;3(2):265-277.

[4] Souza Rd, Ambrosini A, Passaglia LM. Plant growth-promoting bacteria as inoculants in agricultural soils. Genet Mol Biol. 2015 Dec;38(4):401-419.

[5] Zahran HH. Rhizobia from wild legumes: diversity, taxonomy, ecology, nitrogen fixation and biotechnology. Journal of Biotechnology. 2001 Oct; 91(2-3):143-153.

[6] Hallama M, Pekrun C, Lambers H, Ellen K. Hidden miners - the roles of cover crops and soil microorganisms in phosphorus cycling through agroecosystems. Plant Soil. 2019 January 15; 434:7-45.

[7] Binh Thuan Agriculture Promotion Center [Internet]. 2016 [cited 2021 May 1]. Available from: http://www.khuyennong.binhthuan.gov.vn/News/FaqView.aspx?ID=66

[8] Kosty MA, Pule-Meulenberg F, Humm EA, Martínez-Hidalgo P, Maymon M, Mohammadi S, et al. Isolation of potential plant growth-promoting bacteria from nodules of legumes grown in arid Botswana soil. bioRxiv. 2020 September. Available from: https://www.biorxiv.org/content/10.1101/2020.09.02.257907v1.full

[9] Pham TN, Nguyen Thi AL, Pham VN, Dang Thi NT. Morpho-anatomical characteristics and antimicrobial activity of crude extract of Tephrosia villosa (L.) Pers. growing on sandy soil of Phan Thiet City, Binh Thuan Province, Vietnam. World Journal of Advanced Research and Reviews. 2020 December 20;08(03):192-203.

[10] Dang Thi NT, Cao ND. Isolation, Characterization and Identification of Endophytic Bacteria in Maize (Zea mays L.) Cultivated on Acrisols of the Southeast of Vietnam. American Journal of Life Sciences. 2014 August 30;2(4):224233.

[11] Dang Thi NT, Do Thi TT. Isolation and characterization of plant growth promoting rhizobacteria in black pepper (Piper nigrum L .) cultivated in Chon Thanh and Loc Ninh districts of Binh Phuoc province, Vietnam. International Journal of Innovations in Engineering and Technology. 2018 April;10(1):1-10.

[12] Gordon SA, Weber RP. Colorimetric estimation of indoleacetic acid. Plant physiol. 1951;26(1):192-195.

[13] Cao ND. Endophytic bacteria. Can Tho: Can Tho University Press; 2010.

[14] Poonar N, Tak N, Parihar R, Rathore MS, Fox SL, Swift R, et al. Screening of root nodule endophytes isolated from native legumes of arid regions of India for their multiple PGP traits. In: 15th Australian Nitrogen Fixation Conference, 8 - 13 November, Margaret River, Western Australia. 2009; p.58.

[15] Andrews M, Andrews ME. Specificity in Legume-Rhizobia Symbioses. Int J Mol Sci. 2017 March 26;18(4):705.

[16] Rivas R, Abril A, Trujillo ME, Velázquez E. Sphingomonas phyllosphaerae sp. nov., from the phyllosphere of Acacia caven in Argentina. Int J Syst Evol Microbiol. 2004 November;54(6):2147-2150. 
[17] Liu Y, Wang H, Sun X, Yang H, Wang Y, Song W. Study on mechanisms of colonization of nitrogen-fixing PGPB, Klebsiella pneumoniae NG14 on the root surface of rice and the formation of biofilm. Curr Microbiol. 2011 April;62(4): 1113-1122.

[18] Liu D, Chen L, Zhu X, et al. Klebsiella pneumoniae SnebYK Mediates Resistance Against Heterodera glycines and Promotes Soybean Growth. Front. Microbiol. 2018 June 1;9:1134.

[19] Andrés-Barrao C, Lafi FF, Alam I, de Zélicourt A, Eida AA, Bokhari A, et al. Complete Genome Sequence Analysis of Enterobacter sp. SA187, a Plant Multi-Stress Tolerance Promoting Endophytic Bacterium. Front. Microbiol. 2017 October 20;8:2023.

[20] Jorquera MA, Hernández MT, Rengel Z, Marschner P, de la Luz Mora M. Isolation of culturable phosphobacteria with both phytate-mineralization and phosphate-solubilization activity from the rhizosphere of plants grown in a volcanic soil. Biology and Fertility of Soils. 2008 September 1;44(8):1025-1034.

[21] Saggu SK, Mishra PC. Characterization of thermostable alkaline proteases from Bacillus infantis SKS1 isolated from garden soil. PLoS One. 2017 November 30;12(11): e0188724. Available from: https://www.ncbi.nlm.nih.gov/pmc/articles/PMC5708770/ 